\title{
The impact of climatic patterns on runoff and irrigation water allocation in an arid watershed of northern Mexico
}

Ignacio Sanchez Cohen, Marco Antonio Inzunza Ibarra, Gerardo Esquivel Arriaga, Julian Cerano Paredes, Miguel Agustin Velasquez Valle, Palmira Bueno Hurtado

National Institute for Forestry Agriculture and Livestock Research of Mexico, Sede Central: Colonia Barrio de Santa Catarina, Delegación Coyoacán, Distrito Federal CP. 04010, Mexico, e-mail: sanchez.ignacio@inifap.gob.mx

\author{
Waldo Ojedna Bustamante \\ Mexican Institute for Water Technology, Blvd. Paseo Cuauhnáhuac 8532, Progreso, 62550 Jiutepec, Mor., Mexico, \\ e-mail:wojeda@tlaloc.imta.mx
}

\begin{abstract}
The uncertainty of water availability is the main problem in planning for water resources in watersheds of agricultural drylands. Water availability for different uses depends on the runoff that is generated in the upper portion of the watersheds, where there are higher elevations and lower temperatures. Proximity to the ocean is a main factor that defines rainfall amounts. In this research we linked the effects of El Niño to a regional Standardized Precipitation Index $(S P I)$ and the subsequent impact on runoff production and irrigation water allocation. Findings indicate the cascading impacts of the El Niño on the SPI, the SPI on the runoff discharge to the irrigation reservoir, and the final impact on the planted area within the irrigation district. An optimization procedure was applied to maximizing net income in agriculture under different water availability scenarios. The restrictions to the optimization model were: total available water, crop water demand, and available land. Local criteria for defining the maximum allowable planted area by crop also were taken into account. The analysis with various water availability scenarios demonstrated that with limited amounts of water for irrigation, forage area would be limited, thereby increasing the area of crops with lower water demands. In both scenarios the area of forage maize was reduced from 11300 to 1764 ha. Increasing irrigation water use efficiency may save water for expanding the irrigated area, or for other uses.
\end{abstract}

Keywords: $E N S O, S P I$, watershed, cropped area, irrigation

Submitted 14 March 2018, revised 24 April 2018, accepted 8 May 2018

\section{Introduction}

Climate variability, water scarcity, and water quality have been important issues for many countries. Thus, there is a need for planning preventive measures for avoiding huge impacts on human populations; water resources are essential to health as well as social and economic development. According to The Water Project (2018) water status within various nations may take distinctive forms: physical water scarcity or low quantity of water, and economic water scarcity or low quality of water. The agricultural sector is more concerned about the availability of sufficient water for irrigation than in its quality; nevertheless, agricultural water management has been shown to have impacts on the sustainability of the agricultural sector; see, for example, Ayers and Westcot (1994).

In many parts of the world water availability for the different users depends on the runoff that it is generated in the upper portions of the watersheds where there are higher elevations and lower temperatures. In watersheds of northern Mexico rainfall and runoff amounts are tied to climatic oscillations of the Pacific Ocean, affecting agriculture in the lower areas of watersheds.

In Mexico about 25 million ha are cultivated yearly (nearly $30 \%$ of the total area of the country). Of that amount, 6.5 million ha are within irrigation districts and irrigation units, which use almost $77 \%$ of the total water available (Sánchez et al. 2002). The remainder of the area is rain-fed agriculture. Agricultural and livestock production accounts for $65.5 \mathrm{~km}^{3}$ of yearly water use; urban use accounts for $12.5 \mathrm{~km}^{3}$. The yearly average availability of water per person is $3736 \mathrm{~m}^{3}$. This average is biased, because there is a huge imbalance in water availability and rainfall distribution throughout the country. In this way, the southern portion of the country, with $23 \%$ of the total population, accounts for $67 \%$ of total water availability and contributes only $20.2 \%$ of the GDP. On the other hand, the northern part of the country, with $77 \%$ of the population, accounts for $33 \%$ of total water availability and contributes $79.8 \%$ of the GDP (CNA 2015). It is this 
portion of the country where the main irrigation districts are located.

Irrigated agriculture in the northern part of the country is heavily dependent upon water storage in the reservoirs, which in turn depends on rainfall and runoff events. As previously outlined, these events are tied to global climatic patterns such as El Niño Southern Oscillation (ENSO) (Li et al. 2013). Thus, planning for any agricultural year in the irrigation districts of Mexico takes into account the water storage in the reservoirs at the end of the month October of the previous year. After the balance of the basin is determined, producers meet with water authorities to discuss the crop pattern in the irrigation district that should be authorized according to the yearly storage in the reservoir and the producer's water rights.

In this paper we aim to link the ENSO events to the regional Standardized Precipitation Index $(S P I)$ and consequent water availability in the middle part of a watershed in northern Mexico. The water availability, in turn, rules the decision-making process for delivering water to irrigation users.

We also seek to propose crop patterns in the irrigation district that maximize net return and water productivity under various water availability scenarios.

\section{Materials and methods}

\subsection{Study area description}

The analysis performed in this paper was applied to the Nazas watershed in the northern portion of Mexico. This watershed is located within Hydrological Region No. 36 of the Nazas and Aguanaval Rivers; it has a surface area of $18321.64 \mathrm{~km}^{2}$ and a perimeter of 1162.12 km. (INEGI 2018; Fig. 1). The watershed encompasses the Ramos River (including the rivers Tepehuanes and Santiago) and the del Oro or Sextin River from which surface runoff is stored in the Lazaro Cardenas Reservoir. The highest elevation of the watershed is $3300 \mathrm{~m}$ ASL and the lowest $1400 \mathrm{~m} \mathrm{ASL}$. The study region represents the condition of most watersheds in the arid portion of northern Mexico. For assessing the impact of the ENSO within the region, we used daily rainfall data from 17 climate stations located upstream in the Nazas River basin. The climatic stations are operated by the National Meteorological Service of the National Water Commission. The criteria for selecting the stations were (1) to have at least 30 years of consecutive information with no more than $10 \%$ of missing information and (2) having been operated at least through 2005. Afterwards a consistency and homogeneity analysis of the climatic information was performed for verifying the usefulness of the data. (Esquivel et al. 2018; Table 1).

\subsection{Irrigation district description}

Irrigation District 017 encompasses the municipalities of Gomez Palacio, Lerdo, Tlahualilo, Nazas, Rodeo, Mapimi, San Juan de Guadalupe, and Simon Bolivar within the state of Durango, and the municipalities of Torreon, Matamoros, San Pedro de las Colonias, Francisco I. Madero and Viesca within the state of Coahuila. The irrigation district includes 20 irrigation modules, of which 17 correspond to the Nazas River and 3 to the Aguanaval River. The district has a surface area of 223822 ha with an average annual franchised volume of

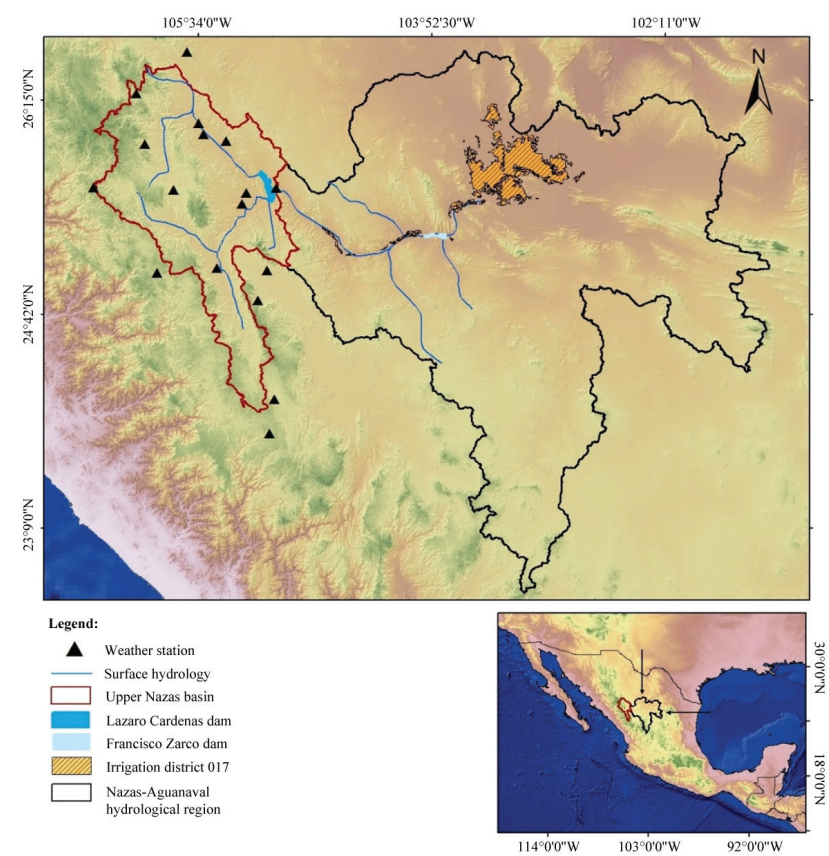

Fig. 1. Location of the study area in Hydrologic Region No. 36, Nazas River in Northern Mexico 
Table 1. Climate stations included in the analysis of the watershed

\begin{tabular}{|c|l|c|c|c|c|c|}
\hline No. & Station & $\begin{array}{c}\text { Height } \\
\text { (MASL) }\end{array}$ & $\begin{array}{c}\text { Yearly average } \\
\text { precipitation }[\mathrm{mm}]\end{array}$ & Latitude & Longitude & $\begin{array}{c}\text { Availability } \\
\text { of information }\end{array}$ \\
\hline 1 & Santiago Papasquiaro & 1822 & 553 & $25^{\circ} 03^{\prime} 00^{\prime \prime}$ & $105^{\circ} 24^{\prime} 55^{\prime \prime}$ & $1922-2016$ \\
\hline 2 & Guanaceví & 2181 & 629 & $25^{\circ} 55^{\prime} 59^{\prime \prime}$ & $105^{\circ} 57^{\prime} 06^{\prime \prime}$ & $1922-2016$ \\
\hline 3 & El Palmito & 1545 & 370 & $25^{\circ} 36^{\prime} 52^{\prime \prime}$ & $105^{\circ} 00^{\prime} 13^{\prime \prime}$ & $1941-2016$ \\
\hline 4 & Cendrandillas & 2423 & 617 & $26^{\circ} 16^{\prime} 58^{\prime \prime}$ & $106^{\circ} 00^{\prime} 38^{\prime \prime}$ & $1961-2014$ \\
\hline 5 & Chinacates & 2105 & 427 & $25^{\circ} 00^{\prime} 36^{\prime \prime}$ & $105^{\circ} 12^{\prime} 42^{\prime \prime}$ & $1963-2014$ \\
\hline 6 & Otinapa & 2369 & 669 & $25^{\circ} 03^{\prime} 13^{\prime \prime}$ & $105^{\circ} 00^{\prime} 31^{\prime \prime}$ & $1963-2013$ \\
\hline 7 & Rosario & 1858 & 457 & $25^{\circ} 30^{\prime} 22^{\prime \prime}$ & $105^{\circ} 38^{\prime} 39^{\prime \prime}$ & $1963-2008$ \\
\hline 8 & El Tarahumar & 2610 & 926 & $25^{\circ} 37^{\prime} 01^{\prime \prime}$ & $106^{\circ} 19^{\prime} 28^{\prime \prime}$ & $1964-2009$ \\
\hline 9 & Navíos viejos & 2587 & 786 & $25^{\circ} 50^{\prime} 04^{\prime \prime}$ & $105^{\circ} 02^{\prime} 30^{\prime \prime}$ & $1964-2014$ \\
\hline 10 & Cienega de Escobar & 2218 & 559 & $25^{\circ} 36^{\prime} 03^{\prime \prime}$ & $105^{\circ} 44^{\prime} 47^{\prime \prime}$ & $1965-2008$ \\
\hline 11 & Santa María del Oro & 1746 & 564 & $25^{\circ} 57^{\prime} 12^{\prime \prime}$ & $105^{\circ} 22^{\prime} 00^{\prime \prime}$ & $1967-2016$ \\
\hline 12 & Tejamen & 2143 & 691 & $24^{\circ} 48^{\prime} 30^{\prime \prime}$ & $105^{\circ} 08^{\prime} 02^{\prime \prime}$ & $1969-2014$ \\
\hline 13 & Sardinas & 1722 & 503 & $26^{\circ} 05^{\prime} 03^{\prime \prime}$ & $105^{\circ} 33^{\prime} 57^{\prime \prime}$ & $1970-2016$ \\
\hline 14 & Los altares & 2549 & 827 & $24^{\circ} 59^{\prime} 20^{\prime \prime}$ & $105^{\circ} 53^{\prime} 30^{\prime \prime}$ & $1973-2016$ \\
\hline 15 & Tejamen & 1663 & 575 & $26^{\circ} 00^{\prime} 16^{\prime \prime}$ & $105^{\circ} 31^{\prime} 36^{\prime \prime}$ & $1976-2008$ \\
\hline 16 & General Escobedo & 1643 & 575 & $25^{\circ} 30^{\prime} 00^{\prime \prime}$ & $105^{\circ} 15^{\prime} 00^{\prime \prime}$ & $1979-2016$ \\
\hline 17 & Inde & 1642 & 357 & $25^{\circ} 34^{\prime} 32^{\prime \prime}$ & $105^{\circ} 13^{\prime} 11^{\prime \prime}$ & $1979-2009$ \\
\hline
\end{tabular}

1.024 million $\mathrm{m}^{3}$, which irrigates 93409 ha and benefits 37956 water users (Macías Rodríguez et al. 2007).

The irrigated surface varies depending upon the volume of water in the reservoirs, which in turn depends on rainfall and runoff patterns in the upper watershed.

\subsection{Data analysis}

Sea surface temperature is the basis for the ENSO index among the international scientific community. Internationally, the El Niño regions have been divided into four sub-regions: Niño 1+2, Niño 3, Niño 3.4 and Niño. The regions and numbers are tied to the marine routes within these regions (Trenberth, Stepaniak 2001; NCAR 2017). For this study sub-region Niño 3.4 has been used for projecting the impact of El Niño on the water resources in the study watershed. Therefore, we correlated the ENSO 3.4 data with the SPI for the watershed, according the study of Li et al. (2013).

\subsection{Precipitation data}

The Standardized Precipitation Index (SPI) quantifies not only precipitation deficit but also precipitation excess for different time scales; the procedure involves the adjustment of the two-parameter gamma probabilistic model, which is transformed to a normal distribution of the variable SPI (McKee et al. 1993). A positive value of the $S P I$ represents a wet period whereas a negative value represents a dry spell. SPI values range from +2 (extremely wet) through -2 (extremely dry).

The SPI was obtained for the region after computing the index for each of the 17 climatic stations included in the project. For obtaining the regional SPI, internal variations of this index were checked using principal components analysis.

\subsection{Runoff data}

Runoff data for the region were obtained from the National Water Commission of Mexico through the National Depository of Data of Surface Water (CNA 2018). This data base contains the daily flow of the main rivers of Mexico $\left[\mathrm{m}^{3} \mathrm{sec}^{-1}\right]$ as well as the volume that the reservoirs capture after each runoff event $\left[\mathrm{m}^{3}\right]$.

\section{Results}

Figure 2 shows the relationship between the ENSO and the SPI for the study region. The analysis extends through 2005, covering the available record ( $\mathrm{Li}$ et al. 2013). From this figure it can be seen that the trend of the SPI resembles that of the ENSO, indicating the influence of the latter on the former, with some variations. The presence of wet and dry years is characterized by the highs and lows of the series, respectively.

There is information through 2016 about runoff generated in the watershed, permitting the expansion of the 


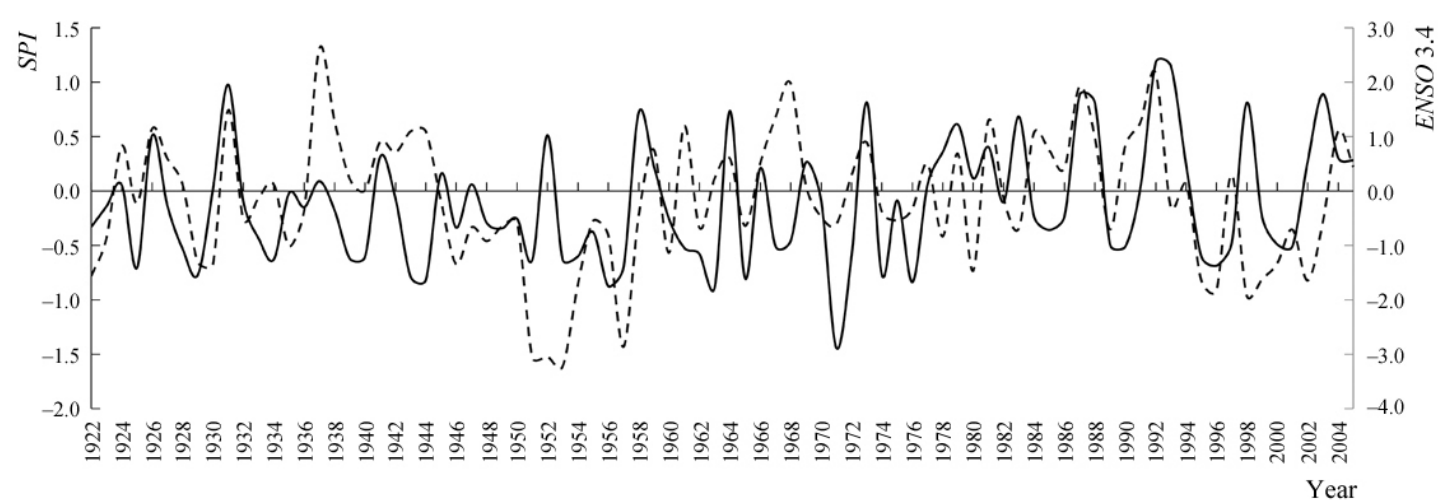

Fig. 2. Relationship between the ENSO (solid line) and the SPI (dotted line) for the study region

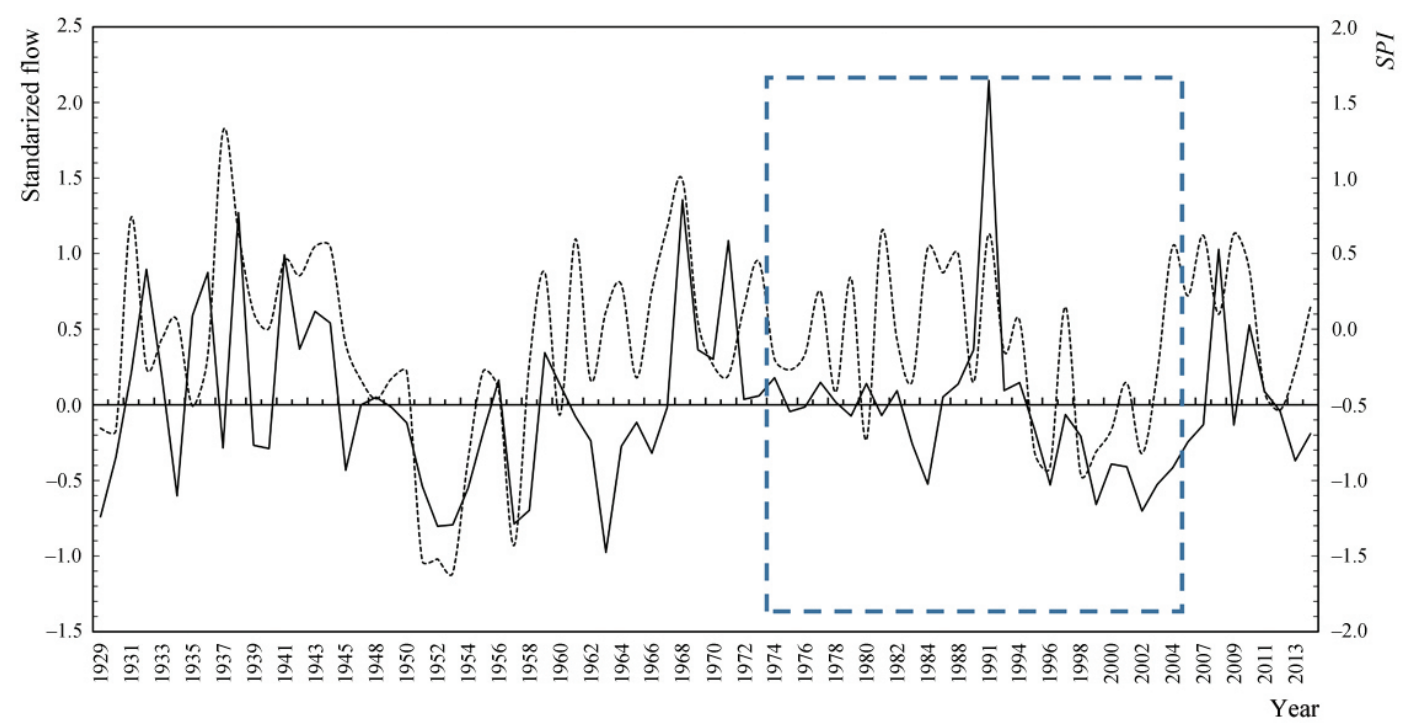

Fig. 3. Relationship between the SPI (dotted line) and the flows to the reservoir (solid line) for the study region. The inset frame encompasses the data availability for ENSO episodes

trend of Fig. 2 to show that these variations have had an impact on runoff to the storage reservoir that feeds the irrigation district lower in the watershed. In Figure 3 the relationship between the SPI and the runoff is shown. The flows have been standardized following the work of Zhai et al. (2010) as:

$$
Q s=\frac{Q i-\widehat{Q}}{\widehat{Q}}
$$

where $Q s$ is the standardized flow, $Q i$ is the $i^{\text {th }}$ observed flow and is the average flow.

The variability of the SPI in the watershed has affected the runoff to the Lazaro Cardenas reservoir and hence has had an impact on the planted area within the irrigation district, as shown in Fig. 4.

The correlation coefficients for the dependent variables SPI and Planted Area are of significance at 95\% confidence, with $\mathrm{p}$ values of 0.04 and 0.0005 , respectively (one-tailed test), below the threshold for significance $(\alpha=0.05)$. The corresponding $t$ values support the evidence against the null hypothesis that there is no significant difference between the population mean and a hypothesized value. For the dependent variable $Q$, the correlation coefficient is significant at $\alpha=0.10$.

According to the results, for a wet $\operatorname{SPI}(\approx 1)$, the flow to the reservoir will increase about $7.87 \mathrm{~m}^{3} \cdot \mathrm{sec}^{-1}$, leading to an increase in planted area of 23849 ha. On the other hand,

Table 2. Statistical parameters for the linear regression analysis

\begin{tabular}{|c|c|c|c|c|c|c|}
\hline \multirow{2}{*}{$\begin{array}{l}\text { Predicted } \\
\text { variable }\end{array}$} & \multirow{2}{*}{ Constant } & \multicolumn{2}{|c|}{ Coefficient } & \multirow{2}{*}{$t$} & \multirow{2}{*}{$p$} & \multirow{2}{*}{$\begin{array}{r}\text { Standard } \\
\text { coefficien }\end{array}$} \\
\hline & & SPI & ENSO & & & \\
\hline$Q$ & 33.08 & 7.874 & & 1.331 & 0.09 & 0.248 \\
\hline$S P I$ & -0.073 & & 0.164 & 1.713 & 0.04 & 0.361 \\
\hline AREA & 50670.235 & 23849.579 & & 4.244 & 0.0005 & 0.717 \\
\hline
\end{tabular}




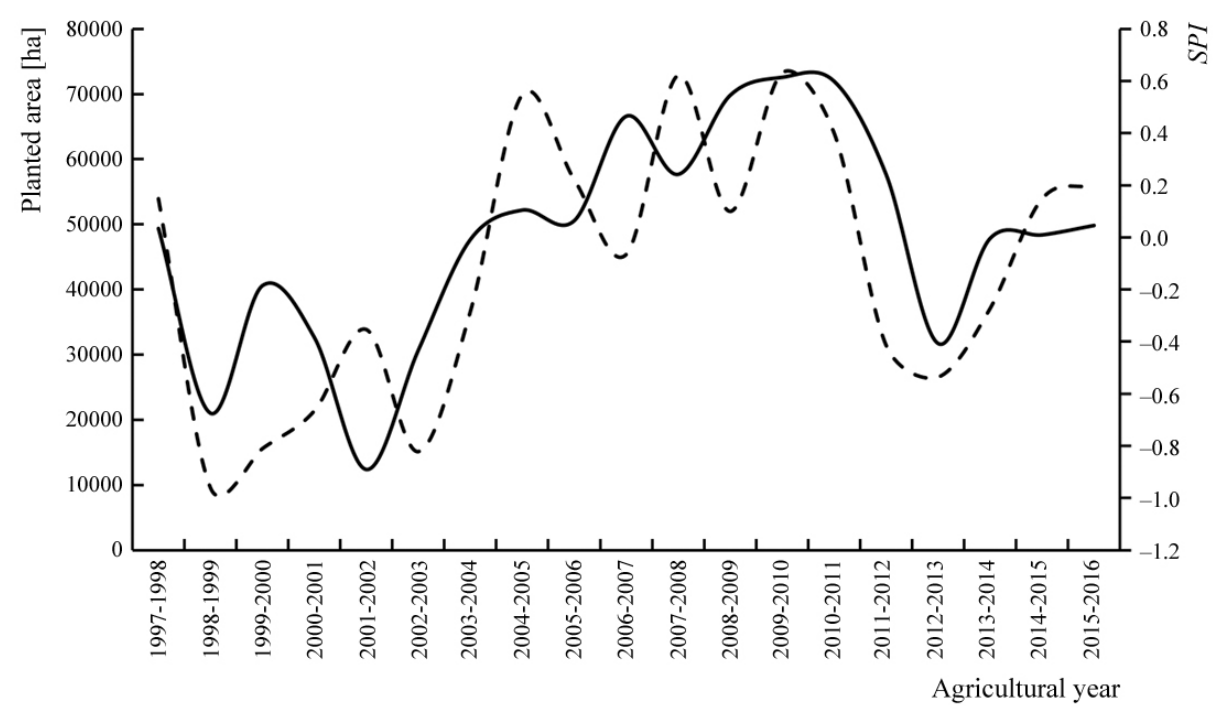

Fig. 4. Time variation of planted area (irrigated) for a given year (solid line) in the irrigation district as a function of the SPI (dotted line); for a wet SPI $(>0)$ planted area tends to increase and for a dry $\operatorname{SPI}(<0)$ the planted area decreases; the correlations and statistical significance of the trends of Fig. 2, 3 and 4 above are shown on Table 2

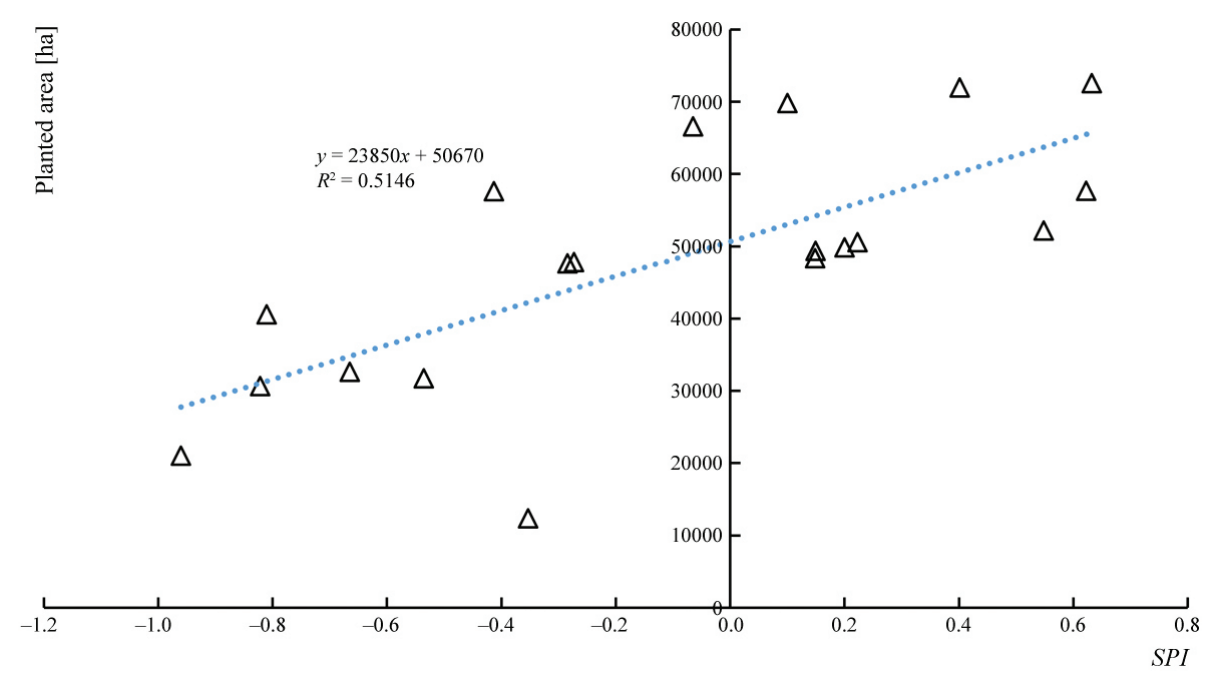

Fig. 5. Statistical correlation between $S P I$ and planted (irrigated) area; as the $S P I$ increases, so does the planted area, since $S P I>0$ indicates a wet year

for a moderate ENSO 3.4 index $(\approx 1)$, the $S P I$ will increase about 0.164 units with impacts on the flow to the reservoir.

Nevertheless, the volume delivered to the irrigation water users in any given year depends on the storage volume in the reservoir during October of the previous year.

Of special interest is to expand the correlation between the SPI and planted area shown in Fig. 4; in this way, Fig. 5 shows the statistical correlation between these two variables.

\section{Water allocation criteria}

According to the irrigation district regulations, the irrigation district managers allocate the irrigation water according to the water balance in the reservoir up to the end of October. The historical crop pattern from the agricultural year 1997-1998 through 2015-2016 is shown in Table 3. In the last two columns the presence of the
El Niño or La Niña is marked to show the lagged impact of these phenomena through time.

The predominant crops within the irrigation district have been forage, since this part of the country is the main milk producer of Latin America. It accounts for more than 230000 head of cattle that produce about 6 million L of milk daily (Sánchez Cohen et al. 2016).

An optimization procedure was undertaken to assess the economic feasibility of the traditional crop pattern under limited amounts of water for irrigation. In this way, an objective function was proposed for maximizing net income, having as constraints: (1) the number of ha to be planted according the historical record of allowable cropped area; (2) the total water volume needed to fulfil the evapotranspiration needs of each crop; and (3) the availability of water in the reservoir. Two scenarios were considered: below average availability of water (year 1998- 
Table 3. Historical crop patterns and areas [ha] for Irrigation District 017 from 1977 through 2016

\begin{tabular}{|c|c|c|c|c|c|c|c|c|c|c|c|c|c|}
\hline \multirow[b]{2}{*}{ Year } & \multicolumn{11}{|c|}{ Crop } & \multicolumn{2}{|c|}{ Climate } \\
\hline & 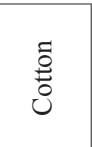 & 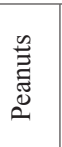 & 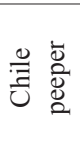 & ڤ్ల & 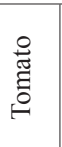 & 蒫 & 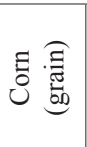 & 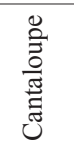 & 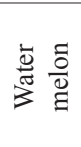 & 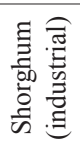 & 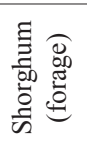 & $\frac{\stackrel{9}{Z}}{\text { 竎 }}$ & 茎 \\
\hline 1997-1998 & 16100 & 251 & 753 & 4861 & 780 & 6738 & 2919 & 861 & 779 & 2601 & 3889 & $\begin{array}{l}\text { Very } \\
\text { strong }\end{array}$ & \\
\hline 1998-1999 & 5413 & 10 & 221 & 725 & 57 & 2203 & 343 & 790 & 540 & & 2951 & & strong \\
\hline 1999-2000 & 7048 & & 1318 & 1055 & 207 & 8737 & 1956 & 689 & 993 & & 5465 & & Strong \\
\hline 2000-2001 & 7692 & 50 & 538 & 478 & 577 & 6717 & 1361 & 654 & 671 & & 2535 & & Weak \\
\hline 2001-2002 & 1120 & & 190 & 356 & 64 & 2652 & 21 & 360 & 85 & 721 & 2019 & & \\
\hline $2002-2003$ & 4497 & 95 & 628 & 1060 & 276 & 10077 & 308 & 1013 & 1307 & 2047 & 2871 & Moderate & \\
\hline 2003-2004 & 13590 & & 1240 & 272 & 556 & 15691 & 445 & 924 & 495 & 1836 & 3607 & & \\
\hline 2004-2005 & 17284 & 257 & 1950 & 178 & 604 & 12031 & 3974 & 796 & 890 & 2415 & 3246 & Weak & \\
\hline 2005-2006 & 15866 & 260 & 1849 & 177 & 612 & 11982 & 3970 & 792 & 855 & 2365 & 3242 & & Weak \\
\hline 2006-2007 & 18066 & 129 & 518 & 69 & 145 & 21227 & 28 & 1624 & 1298 & 603 & 12833 & Weak & \\
\hline $2007-2008$ & 14324 & 137 & 477 & 15 & 10 & 15297 & 881 & 1090 & 1327 & 1084 & 13710 & & Strong \\
\hline 2008-2009 & 16522 & 85 & 1151 & 89 & 361 & 16888 & 905 & 1003 & 489 & 1277 & 19164 & & Weak \\
\hline 2009-2010 & 23299 & 100 & 644 & 80 & 389 & 14842 & 517 & 1400 & 1034 & 1678 & 15183 & & \\
\hline 2010-2011 & 23197 & 100 & 572 & 64 & 480 & 14224 & 605 & 1024 & 369 & 1736 & 16960 & & Strong \\
\hline 2011-2012 & 16610 & 90 & 270 & 30 & 310 & 11506 & 470 & 554 & 244 & 218 & 15520 & & Moderate \\
\hline $2012-2013$ & 5788 & 10 & 209 & 4 & 50 & 4352 & 384 & 464 & 140 & 84 & 10948 & & \\
\hline 2013-2014 & 12654 & 200 & 497 & 7 & 123 & 7571 & 487 & 443 & 345 & 249 & 13816 & & \\
\hline 2014-2015 & 11674 & 200 & 590 & 9 & 225 & 9461 & 447 & 495 & 586 & 42 & 13075 & Weak & \\
\hline 2015-2016 & 10284 & 200 & 630 & 2 & 296 & 22295 & 62 & 945 & 438 & 142 & 3853 & $\begin{array}{c}\text { Very } \\
\text { strong }\end{array}$ & \\
\hline
\end{tabular}

1999) under the influence of the strong La Niña event, and a scenario with a moderate El Niño event (2002-2003), see Table 3. No further scenarios with sufficient water in the reservoir were analyzed since under this condition the available land (within the limits of the irrigation district) and water for irrigation will be unlimited. The objective function and their restrictions have the form of:

A. For the objective function:

$$
\max (N I) \sum_{c=1}^{N} M p \cdot F[\mathrm{ha}]
$$

where $N I$ is the net income to be maximized, $c$ is a particular crop, $N$ is the total number of crops, $M p$ is the market price and $F$ is the number of ha to be planted.

B. For the restriction on availability of land:

$$
\sum_{c=1}^{N} \leq \text { Available land }
$$

The available land refers to the total irrigable land and the total area to be planted should not exceed this amount. C. For the restriction of available water volume:

$$
\sum_{c=1}^{N} F \cdot E \mathrm{t} \leq \text { Available volume }
$$

where $E t$ is the evapotranspiration or crop water needs. The available volume is that in the runoff collecting reservoir and the amount to be used (equation 4) is a function of the water user's association criteria considering the National Water Commission regulations.

An additional restriction to the model was the maximum allowable limit to plant for each crop to be considered in the crop pattern. This value considers economic and social inputs. For instance, if the water user's association decides to plant the whole area of the irrigation district with the crop that generates the most revenues, then the market price will be affected with a serious impact on the regional economy. On the other hand, if the selected crops are those with the higher water demands, then the crop pattern resulting from the optimization procedure will be affected, reducing the number of ha to be planted according to the availability of water in the reservoir. So, for this study the average crop area planted historically was considered within the optimization procedure.

For the objective function, in each scenario analyzed the market prices were set to those prevailing within the 
respective year according the National System of Agricultural Information (SIAP 2018). In both scenarios the objective function maximized net income by restricting the planted area of forage crops, given their comparatively low earnings per ton and the relatively higher water use. Forage maize was restricted from a proposed 11300 ha down to 1764 ha. Under the limited water availability scenario, the crops with higher market prices and lower evapotranspiration comprise the solution of the objective function. Crops entering the solution were: cotton, peanuts, chili, tomato, forage maize, grain maize, beans, industrial sorghum, forage sorghum, cantaloupe, and watermelon. An increase in irrigation water use efficiency may increase the planted area by saving water for other less water demanding crops.

The scheme for the analysis of the impact of global climate patterns presented in this paper may help decisionmakers in the irrigation districts to plan in advance the area that should be planted given the behavior of the ENSO and $S P I$ indexes. The $S P I$ is readily computed and, since its value is influenced by the ENSO, planners may use the $S P I$ index for an objective computation of possible available volumes of water for irrigation.

\section{Conclusions}

The impact of ENSO on the northern part of Mexico has been assessed indicating the cascading effect this climatic pattern has on the agriculture of the watersheds of this part of the country. The nested algorithms used are useful for planning water assets for agriculture under different climate scenarios. Even though the study was directed only to a watershed located in the northern part of Mexico, the analytical process may serve for data from any watershed that may be influenced by this climatic phenomenon. The SPI is an efficient yet easy tool for measuring this impact with readily available information. If there is available information on runoff within the watershed of interest, then an economic analysis may be performed to synthesize information for planning irrigated agriculture in the lower watershed. The optimization of net income is of crucial importance in maximizing water productivity as a decision variable under different water availability scenarios. For this study, results have indicated the need for shifting to less water-demanding crops, reducing the planted area of forage crops even though they sustain a very important industry (milk) that in turn stimulates the local economy. Nevertheless, the ecological implications of an economic benefit analysis should prevail within the decision-making regime when allocating limited amounts of water within the region. Increasing water use efficiency in the irrigated agriculture sector should play an important role, since competition among water users (agricultural, households, industry, etc.) is increasing and the agricultural sector remains as the main user of the water resources of the country $(77 \%)$. The analytical processes used in this paper serve to downscale a global phenomenon ENSO to local impacts.

\section{Bibliography}

Ayers R.S, Westcot D.W., 1994, Water quality for agriculture, FAO Irrigation and Drainage Paper, 29, available at http:// www.fao.org/docrep/003/t0234e/t0234e00.HTM (data access 11.05.2018)

CNA, 2015, Atlas del agua en Mexico, Comisión Nacional el Agua, available at http://www.conagua.gob.mx/CONAGUA07/Publicaciones/Publicaciones/ATLAS2015.pdf (data access 11.05.2018)

CNA, 2018, Comisión Nacional el Agua, available at ftp://ftp. conagua.gob.mx/Bandas/Bases_Datos_Bandas (data access 11.05.2018)

Esquivel A.G., Cerano Paredes J., Sánchez Cohen I., Velasquez Valle M.A., Flores Lopez F., Bueno Hurtado P., 2018, Influencia de ENSO en la variabilidad de la precipitación en la cuenca alta del Nazas, México, Journal Tecnología y Ciencias del Agua, (in press)

INEGI, 2018, Instituto Nacional de Estadística y Geografía, available at http://antares.inegi.org.mx/analisis/red_hidro/siatl/\# (data access 11.05.2018)

Li J., Xie S.-P., Cook E.R., Morales M.S., Christie D.A., Johnson N.C., Chen F., D’Arrigo R., Fowler A.M., Gou X., Fang K., 2013, El Niño modulations over the past seven centuriesm Nature Climate Change, 3, 822-826, DOI: 10.1038/ nclimate 1936

Macías Rodríguez H., Sánchez Cohen I., Catalán Valencia E.A., 2007, A decision support system for integrated water management in the irrigation district no. 017, Coahuila and Durango, Mexico, Revista Chapingo Serie Zonas Aridas, 6, 77-89

McKee T.B., Doesken N.J., Kleist J., 1993, The relationship of drought frequency and duration to time scale, [in:] Proceedings of the Eighth Conference on Applied Climatology, 17-22 January 1993, Anaheim, California, American Meteorological Society, Boston, 179-184

NCAR, 2017, Climate Data Guide: Nino SST indices (Nino 1+2, 3, 3.4, 4; ONI and TNI), National Center for Atmospheric Research Staff, available at https://climatedataguide.ucar. edu/climate-data/nino-sst-indices-nino-12-3-34-4-oni-andtni (data access 11.05.2018)

Sánchez Cohen I., Estrada Avalos J., Gonzales Cervantes G., 2002, Irrigation technology in the irrigation districts of 
Mexico, Water International, 27 (4), 578-584, DOI: 10.1080/ 02508060208687045

Sánchez Cohen I., Delgado Ramírez D., Esquivel Arriaga G., Bueno Hurtado P., Román López A., 2016, Forage water footprint in the Comarca Lagunera, [in:] Water, food and welfare. Water footprint as a complementary approach to water management in Mexico, R. Pérez-Espejo, R.M. Constantino-Toto, H.R. Dávila-Ibáñez (eds.), Springer Briefs in Environment, Security, Development and Peace series, 23, Springer, 199-214

SIAP, 2018, available at http://infosiap.siap.gob.mx:8080/agricola _siap_gobmx/ResumenProducto.do (data access 11.05.2018)
The Water Project, 2018, available at https://thewaterproject.org/ (data access 11.05.2018)

Trenberth K.E., Stepaniak D.P., 2001, Indices of El Niño evolution, Journal of Climate, 14 (8), 1697-1701, DOI: 10.1175/1520-0442(2001)014<1697:LIOENO>2.0.CO;2

Zhai J., Buda S., Krysanova V., Vetter T., Gao C., Jiang T., 2010, Spatial variation and trends in PDSI and SPI indices and their relation to streamflow in 10 large regions of China, Journal of Climate, 23 (3), 649-663, DOI: 10.1175/2009JCLI2968 